\title{
PRIJEPORI OKO NASLIJEĐA PROŠLOSTI I MEMORIJA U HRVATSKOJ: ZNANSTVENO-POPULARNA PUBLIKACIJA POD PRITISKOM IDEOLOGIJA
}

JASNA ČAPO ŽMEGAČ

Institut za etnologiju i folkloristiku

10000 Zagreb, Šubićeva 42
DOI: $10.17234 /$ SEC.27.3

Pregledni rad / Review article

Primljeno / Received: 1. 3. 2015.

Prihvaćeno / Accepted: 15. 7. 2015.

U radu se iznosi teza da u Hrvatskoj supostoje konfliktne memorije ustaštva i komunizma te da sukobi oko režima memorije nastaju na svakodnevnoj razini, unatoč tomu što je 70 odnosno 25 godina proteklo od nestanka ustaškog i komunističkog poretka. Nadalje se tvrdi da su konfliktne memorije reproducirane od strane političara i politiziranih medija te da se upravo zbog toga označitelji "komunist" $i$ "ustaša” osnažuju u svakodnevnom diskursu. U potkrijepu navedenih teza iznosi se kontroverza oko jednoga znanstveno-popularnog zbornika.

Ključne riječi: ideologija, politika, memorija, Hrvatska

Suvremena Europa svjedok je "erupcije kolektivnog pamćenja” (Langenbacher, Niven i Wittlinger 2012:3), posebice vezano uz "dvije europske patologije" (Katunarić 2015), fašizam i komunizam. Povijesna naslijeđa i sjećanja na njih restrukturirana su nakon nestanka socijalizma/ komunizma u Istočnoj Europi 1990-ih odnosno nakon što se Zapadna Europa intenzivnije suočila s holokaustom od 1980-ih naovamo te su do danas vrlo živa (Niven 2012).

Hrvatska sudjeluje u tim europskim procesima memorijalizacije; štoviše, oni dulje vrijeme snažno opterećuju hrvatsku politiku, medije i različite društvene aktere. Uz dva prethodno spomenuta povijesna naslijeđa, suočena je i s naslijeđem rata za neovisnost, Domovinskog rata. Tako se Hrvatska istodobno bavi trećim povijesnim naslijeđem u trenutku u kojem teret prijašnjih povijesnih epoha i zbivanja još nije razriješen te ustaštvo i komunizam zadiru u i miješaju se s najnovijim procesima memorijalizacije. Jedan istraživač tih procesa nedavno je zaključio kako su službene percepcije povijesti u Hrvatskoj u posljednja dva desetljeća promjenjive, nekonzistentne i razdorne što je rezultiralo "manjkom jasnih 
i zajedničkih orijentacija" i raskorakom između sadržaja službenih i privatnih memorijskih narativa (Gudehus 2012:82).

Kontroverzne i duboko podijeljene memorije ustaštva i socijalizma/ komunizma u Hrvatskoj traju do danas, a njihovi se sukobi javljaju na svakodnevnoj bazi unatoč tomu što je prošlo 70 odnosno 25 godina od sloma ustaškog odnosno komunističkog režima. Rasprave oko memorija vezanih uz Drugi svjetski rat i komunizam sadrže pitanje o ulozi ustaša i komunista ili preciznije i, prema Vjeranu Pavlakoviću, najvažnije, pitanja i prijepore kao što su uspostava koncentracijskih logora, suradnja Rimokatoličke crkve i ustaškog poretka, odnos između antifašizma i komunizma i poslijeratna osveta komunista i opća represija (Pavlaković 2014:37). Oba ključna čimbenika političkog života, Socijaldemokratska partija i Hrvatska demokratska zajednica, pridonose održavanju sukobljenih memorija i interpretacija prošlosti. Dok se razlike između njihovih politika sve više smanjuju, one ostaju izrazite u njihovim politikama povijesti i memorijalizaciji povijesnih događaja (Cipek 2009; Pavlaković 2009, 2014). Obje političke stranke manipuliraju prošlošću i pamćenjem kako im odgovara u svakodnevnim političkim suprotstavljanjima. To ima dvostruku posljedicu: s jedne strane, suprotstavljene se memorije stalno reproduciraju i osnažuju te, s druge, hrvatska politička scena zasićena je njihovim spominjanjem i uzajamnim optužbama političara za reviziju interpretacije Drugoga svjetskog rata, ${ }^{1}$ odnosno za ponovno uvođenje komunističke ideologije. Tim optužbama obje strane žele difamirati političke oponente. Neki se utjecajni mediji koriste tim neodgovornim etiketiranjem osobe kao 'komunista' ili 'ustaše', 'političkog revizionista' ili 'komunističkog restauratora”. Pišući o tome, Ivo Banac nedavno je ponovio svoju tezu iz 2009. da je Hrvatska "natopljena mržnjom” (Banac 2014a). Kazao je također kako su današnje anonimne i potpisane internetske rasprave "festivali mržnje, gnjeva i vrijeđanja", a suvremeno stanje društva dijagnosticirao je kao "verbalni

\footnotetext{
${ }^{1}$ To se naziva povijesnim revizionizmom. Prema Tihomiru Cipeku i Vjeranu Pavlakoviću, sastoji se i od rehabilitacije poraženih ustaških kolaboratora i kriminalizacije i demonizacije pobjedničke antifašističke jugoslavenske vojske, partizana (Cipek 2009; Pavlaković 2008, 2009, 2012).
} 
građanski rat”. Slično je mišljenje iskazao Dražen Katunarić ocjenom da je hrvatsko društvo

"društvo travestije, zaborava, relativne istine, sljepila sadašnjosti, ponavljanja pogrešaka prošlosti, međuoptužbi, a ne društvo dijaloga. [...] Takvo društvo ne može imati ni svoju katarzu ni moralnu ravnotežu, nego se gubi u međusobnim optužbama i ideološkom gregarizmu." (Katunarić 2015:4)

Takvo stanje stvari taj je autor pripisao činjenici da se Hrvatska u posljednja dva desetljeća izbjegava suočiti s totalitarnom prošlošću komunističkog režima.

Razlike dviju dominantnih političkih stranaka u pogledima na Drugi svjetski rat i poslijeratnu Jugoslaviju, kao i percepcija koju stanovništvo ima o tim razlikama, baza su za glasačku podršku jednoj ili drugoj i za podjelu na "crvenu i crnu Hrvatsku", tvrdi Pavlaković (2014). Ako je to točno, tada se i rezultati predsjedničkih izbora u siječnju 2015., u kojima je kandidat podržan od HDZ-a pobijedio kandidata SDP-a s vrlo malom razlikom od oko 30000 glasova, mogu interpretirati kao rezultat stalne reprodukcije suprotstavljenih memorija Drugoga svjetskoga rata i poslijeratnog razdoblja koja potiče polarizaciju hrvatskog društva.

Nemogućnost društva i politike da oblikuju kolektivna sjećanja na ustaštvo i komunizam i evaluiraju prošle događaje (Cipek 2009) prelijeva se iz politike i medija na razne dimenzije društva, pa i na akademsku zajednicu. Pojava prijepora oko memorija i ideologija manje začuđuje u svakodnevnoj politici i medijima, premda bismo očekivali da će se i tamo pažljivije i s više odgovornosti rabiti i jedna i druga etiketa. No, u akademskoj zajednici ona doista začuđuje, upućujući na ideologiziranost suvremene hrvatske humanistike i društvenih znanosti (Banac 2014b).

Ovaj se rad bavi gorespomenutim prijeporima u akademskom okruženju vezanim uz zbornik Didov san: transgranična iskustva hrvatskih iseljenika (Čapo, Hornstein Tomić i Jurčević 2014a). Knjiga je neposredno prije objavljivanja znanstveno i politički diskreditirana od kolega iz Instituta za etnologiju i folkloristiku. Politička diskreditacija mogla je 
biti očekivana s obzirom na to da se knjiga bavi iseljeničkom tematikom. Samo otvaranje te teme $u$ hrvatskom društvu, pogotovo ako se ne zazire od prezentacije oprečnih diskursa heterogene iseljeničke populacije, nosi rizik da bude uvučeno u dnevne ideološke razmirice, jer je iseljeništvo, kao i hrvatsko društvo u cjelini, kompleksna i raznolika skupina ljudi podijeljenih stavova i predodžaba o ključnim povijesnim događajima u Hrvatskoj. Hrvatski iseljenici imaju dijametralno različite migracijske pozadine i motive emigriranja u različitim razdobljima (ključni su motivi ekonomski i politički, ponekad u nerazdvojivoj simbiozi; najveći valovi iseljavanja bili su krajem 19. i na prijelazu u 20. stoljeće; između dvaju svjetskih ratova, nakon Drugoga svjetskog rata, 1960-ih). Migracijska pozadina uvjetovala je njihovo djelovanje u inozemstvu (u rasponu od njegovanja regionalnog folklora do političkog aktivizma s ciljem rušenja Jugoslavije i uspostavljanja hrvatske države) te načine njihove prisutnosti u Hrvatskoj (među kojima se u javnosti ističe dijasporski politički aktivizam ranih 1990-ih i prijepori oko toga treba li dijaspori omogućiti glasovanje na izborima u Hrvatskoj).

K tomu, iseljeništvo je u nekim dijelovima hrvatskog društva negativno stereotipizirano. Ta je naslijeđena negativna percepcija iseljeništva formirana u bivšoj Jugoslaviji kao narativ o "neprijateljskoj emigraciji", "nacionalistima", "ustašama", "fašistima" i "teroristima" (Rogić i Čizmić 2011:188ff, usp. Czerwiński 2013). Negativna stereotipizacija iseljeništva bila je sastavni dio ideološke borbe sustava protiv "vanjskih i unutrašnjih neprijatelja". Vezuje se uz činjenicu da nakon poraza ustaške Nezavisne Države Hrvatske 1945., ustaše i protivnici komunizma bježe u emigraciju odakle djeluju protiv jugoslavenskog poretka. Na predstavljanju zbornika Didov san: transgranična iskustva hrvatskih iseljenika, Branko Salaj, ekonomski analitičar i publicist, analizirao je elemente nastanka stigmatizacije iseljeništva u bivšoj Jugoslaviji uputivši na dugotrajnu indoktrinaciju koja je ostavila duboke tragove i prati pisanje o iseljeništvu do danas. ${ }^{2}$ Stereotip o "neprijateljskoj emigraciji", generaliziran na cjelokupnu kompleksnu iseljeničku populaciju, do danas potiče medijski

${ }^{2}$ Knjiga je predstavljena u Matici hrvatskoj u Zagrebu, 12. ožujka 2014. Uz Branka Salaja, o knjizi i o optužbama na račun njezina sadržaja govorili su i Ivo Rogić i Ivo Banac. 
govor o iseljeničkoj "inferiornosti", "nedemokratičnosti" ili "zatucanosti", na što se kritički osvrnuo i Banac na istom događaju (objavljeno u: Banac 2014b).

Zbornik Didov san: transgranična iskustva hrvatskih iseljenika govori o iseljenicima i njihovim potomcima koji su se u posljednja dva desetljeća odlučili na povratak odnosno na doseljavanje u Hrvatsku. Prilozi iz pera etnologa i kulturnih antropologa, povjesničara i lingvista, od kojih neki i sami imaju iskustvo iseljeništva i povratka, bave se iseljeničkim migracijskim trajektorijama, motivima dolaska u Hrvatsku, pripremama koje su prethodile dolasku, migrantskim poimanjima doma i identiteta, govore o snalaženju i životu povratnika u Hrvatskoj. Nastojalo se obuhvatiti iseljenike iz što većeg broja zemalja u kojima postoji značajnija hrvatska iseljenička populacija, bez obzira na to jesu li razlozi njihove emigracije bili pretežito političke ili ekonomske prirode. Osobita je pozornost posvećena potomcima iseljenika, tzv. drugoj migrantskoj generaciji, koji su se odlučili na "povratak" u domovinu svojih predaka (iz Australije, Argentine, Brazila i Njemačke). Riječ je o osobama koje su Hrvatsku ponekad poznavale samo iz priča svojih roditelja i djedova i baka te koje se u njoj nastanjuju (neprecizno je reći da se "vraćaju", jer u Hrvatskoj nisu nikada živjele) i onda kad to nisu uspjeli njihovi preci. Stoga su urednice zborniku dale poetičan naslov, Didov san, u ikavskoj inačici hrvatskih govora.

Knjiga je hibridan proizvod, sastavljena ujedno od znanstvenostručnih radova i od eseja i emotivno obojenih iskaza samih iseljenika nastalih na osnovi intervjua. ${ }^{3}$ Poticaj za prezentaciju iseljeničkih iskaza bez analitičkih komentara dala je kompleksna autorefleksivna migracijska priča Katarine Brozović-Bašić koju sam priredila temeljem višesatnog razgovara s njome. Taj iskaz zauzima središnje mjesto u zborniku (Brozović-Bašić 2014) jer istodobno izvrsno ilustrira glavne znanstvene hipoteze izložene u uvodnom poglavlju i predstavlja izvanredan, gotovo literarni iskaz o migrantičinu životu između Australije i Hrvatske, što je uočio Jozo Džambo u osvrtu na zbornik (Džambo 2015, v. poslije). Urednice su nastojale

\footnotetext{
${ }^{3}$ Upravo zbog takva sadržaja, Ministarstvo znanosti, obrazovanja i sporta kategoriziralo ju je kao "referentno djelo s izvornim doprinosom", a ne kao "znanstveno djelo".
} 
realizirati još nekoliko razgovora s migrantima/povratnicima i prezentirati ih na jednak način: kao posebno uređene priloge u kojima bi dominirali migrantski iskazi. Time su željele dati glas povratnicima u svoj njihovoj različitosti i dobiti autoritativnim znanstvenim glasom neposredovane iskaze migranata. ${ }^{4}$ Također, predmnijevale su da domaćoj javnosti nisu potrebna tumačenja općih društvenih, povijesnih, kulturnih i političkih događaja i okolnosti unutar kojih su nastajale ideje i mišljenja pojedinih migranata. Nadalje, u zborniku koji nije strogo i isključivo znanstvene prirode i ne pretendira razriješiti neka ključna pitanja etnografske metode, rasprava o prezentaciji građe dobivene intervjuima nije im se činila nužnom. ${ }^{5}$

Namjera urednica da temeljem razgovora s različitim iseljenicima postignu multivokalnost te dublji i uvjerljiviji uvid u migrantska iskustva samo je donekle uspjela. Neki su je komentatori i prikazivači knjige prepoznali (Čačić-Kumpes 2014:249; Udier 2014:265; Prtenjača 2014; Rogelja 2015). Drugi su, zbog iskaza Marina Sopte (Sopta 2014b), doveli u pitanje takav postupak uređivanja kazivanja (Pleše 2014:24-25). Čini se da je odlučujuće za takvo mišljenje bila manipulacija sadržajem, a ne forma u kojoj su Soptine riječi prezentirane, jer su i svi drugi razgovori s iseljenicima prezentirani na sličan način, uz neke razlike što su nastale zbog različitih sugovornika $\mathrm{i}$ iskustva istraživača s etnografskom metodom.

U prvotnoj verziji knjiga je obuhvaćala priloge o iseljenicimapovratnicima iz SAD-a, Kanade, Argentine, Australije, Brazila, Austrije i nekoliko priloga o onima iz Njemačke, kao i transkribirane i autorizirane iskaze iseljenika iz Kanade, Brazila, Australije i Argentine. U svom konačnom obliku, a nakon što je troje autora, aktera ideoloških prijepora vezanih uz knjigu, povuklo svoje radove, urednička namjera da se prikažu što raznolikija iseljenička iskustva i stavovi dovedena je u pitanje. Uz spomenute iseljeničke iskaze, preostali su analitički radovi o potomcima hrvatskih iseljenika koji doseljavaju iz Australije, Njemačke i Argentine,

${ }^{4} \mathrm{O}$ toj se metodologiji može raspravljati, no to se urednicama nije činilo nužnim u zborniku koji primarno nije znanstveno djelo.

${ }^{5}$ Niti su svi autori na jednak način u njoj mogli sudjelovati jer nisu etnolozi i kulturni antropolozi. 
prilog o hrvatskom iseljeništvu u Brazilu, o doprinosu kanadskih Hrvata ratu za neovisnost 1990-ih i prikaz iseljeničke tematike u poeziji jednoga političkog emigranta-povratnika iz Austrije. No, izostao je tekst o zanimljivom iskustvu američkih povratnika na jedan dalmatinski otok; o traganju za domom u njemačkom kontekstu, u kojem pripadnici hrvatskog, srpskog i bošnjačkog naroda kroz sjećanje rekonstruiraju nekadašnji svima zajednički jugoslavenski društveni prostor. Konačno, izostao je i prilog o pronalaženju doma u izbjegličko-povratničkom kontekstu triju država Njemačke, Hrvatske i Bosne i Hercegovine. Zbog povlačenja tih radova nestala je prevaga znanstvenih priloga nad iseljeničkim iskazima te se kao ukupan dojam knjige nametnuo znanstveno-popularan pristup.

U ovom radu iznosim tezu da insinuacije da zbornik Didov san: transgranična iskustva hrvatskih iseljenika promiče krajnje desnu ideologiju pa čak i ustaštvo valja analizirati u svjetlu ideoloških i politiziranih sukoba oko memorije u suvremenom hrvatskom društvu. Pisani i usmeni komentari o zborniku, iznošeni nekoliko mjeseci prije i nakon njegova objavljivanja, uglavnom u Institutu za etnologiju i folkloristiku, naglašavaju tezu da je riječ o iskonstruiranom problemu i skandalu koji se primarno nije vodio oko striktno akademskih nego oko politiziranih pitanja i kontroverzi oko sukobljenih memorija o ključnim povijesnim zbivanjima hrvatske prošlosti i njihovoj interpretaciji. Smatram, nadalje, da sukobljene memorije u suvremenoj Hrvatskoj možemo objasniti ne samo nemogućnošću društva i politike da postignu konsenzus oko burnih povijesnih događaja u 20. stoljeću i njihova naslijeđa nego još više konstantnim manipulacijama tim dvama naslijeđima. Bijelo-crnom kontrastu između ustaša i komunista/partizana kojim se služe neki mediji i političari nedostaje nijansirano razumijevanje kompleksnih povijesnih događaja. Kao banalna simplifikacija kodirana u hrvatskoj kulturi (Czerwiński 2013) - no ne i s banalnim posljedicama, taj kontrast odražava tipičan stereotip komunističkoga propagandnog narativa i služi istoj ideološkoj i manipulativnoj funkciji (podjele društva, sijanja straha, politizacije, itd.) kao u socijalističkom/komunističkom razdoblju. Na takav zaključak upućuju i reakcije aktera događaja koje ću opisati.

Kao prvopotpisana suurednica zbornika Didov san: transgranična iskustva hrvatskih iseljenika odgovorno tvrdim da zbornik nije imao skrivenu namjeru da revidira povijesne interpretacije hrvatske inačice 
nacizma/fašizma. Međutim, da je možda bio iskorišten od nekih aktera za promicanje izvjesne političke agende postalo je razvidno tijekom događaja koji su uslijedili nakon što je stekao ekstremno desničarsku, proustašku reputaciju. U trenutku kad je sukob bio na vrhuncu, osjećala sam se uhvaćena između dviju nepopustljivih ideoloških pozicija, i one desnog i one lijevoga političkog spektra. Kao i oni autori koji su povukli svoje priloge zbog straha od kompromitiranja svoga imena u navodno revizionističkom ustaškom ozračju zbornika, osjetila sam duboki nemir i strah. Mjesecima ih je hranilo "uzrujano jato papiga i brbljavih šojki" (Krleža 2000) koje je širilo diskreditirajuće i difamantne ocjene zbornika. U nemogućnosti da prijepor s kolegama raspravim na akademski i neemotivan način, odlučila sam inzistirati na objavljivanju zbornika smatrajući ga vrijednim doprinosom rijetkoj literaturi o hrvatskom iseljeništvu i povratništvu, a činjenica da neke znanstvenice iz Instituta za etnologiju i folkloristiku ustraju na kolportiranju konstrukcije o rehabilitaciji ustaštva i zbornik dovode u kontekst znanstvenih falsifikata, znanstvenoga konformizma i služenja "polugama moći" te simulacije znanstvenosti (Jambrešić Kirin 2014; Pleše 2014; Hameršak et al. 2015) potakla me na objavljivanje ovoga osvrta.

Budući da sam sama bila dionicom sukoba, ovaj presjek događaja oko zbornika će teško umaći mojoj pozicioniranosti, te će vjerojatno biti djelomično nepotpun i obojen mojim stavovima i emocijama (usp. Clifford 1986). Rad ne treba čitati ni kao opravdavanje ni kao molbu čitateljima za razumijevanje moje pozicije i odluka. Sažimajući ključne događaje i izjave, njegov je cilj tumačenje događaja u svjetlu politiziranih ideoloških pozicija za koje smatram da su činile ključnu pozadinu cijele kontroverze i njezinih odvjetaka. Cilj je rada dakle analizirati sukob oko zbornika kao aspekt neriješenoga društvenog konflikta i njegova stalnog osnaživanja u javnoj sferi političkim manipulacijama putem medijskih razglasa. Neću zalaziti u druge moguće aspekte kontroverze, napose one osobne ili metodološke prirode. ${ }^{6}$ Bavit ću se samo onima koje osvjetljavaju moju tezu da je optužba da je zbornik pružio prostor "nedozvoljenom diskursu” (Holmes

${ }^{6}$ Bez obzira na to koliko je osobni motiv možda bio važan, on ostaje izvan akademskog dosega; na metodološke sam se prijepore već kratko osvrnula. 
1993) o ustaštvu bila fabrikacija i manipulacija. Rad vodi zaključku da se neki znanstvenici u Hrvatskoj, kao uostalom i mnogi drugi članovi društva, ne uspijevaju distancirati od vlastite pozicioniranosti i upustiti u njezinu kritičku samorefleksiju. Samozvana kritička etnologija i kulturna antropologija stoga jest “iskočila iz tračnica” (usp. Jambrešić Kirin 2014).

U nastavku članka, prvo predstavljam kritike i insinuacije iznesene na račun zbornika. Nakon toga bavim se reakcijama autora zbornika. Nakon upute na nekoliko akademskih prikaza zbornika, opisujem izvore ideološkog jaza što dijeli hrvatsko društvo. Naposljetku, upućujem na širi kontekst sukoba oko memorije u kontekstu Europske unije.

\section{OD ZNANSTVENOG PREZIRA DO JAVNE DISKREDITACIJE}

Recenziranje znanstvenih tekstova standardna je praksa kako $\mathrm{u}$ Hrvatskoj tako i drugdje. Manje je standardna praksa da objavljivanje knjige koju su recenzenti pozitivno ocijenili, te koja je dobila preporuke za objavljivanje, nekoliko izvora financijske podrške, uključivo i onaj Ministarstva znanosti, obrazovanja i sporta te se nalazi neposredno pred objavljivanjem, bude zaustavljeno dopisom (nazvan "obrazloženje neprihvatljivosti...") urednica biblioteke Nova etnografija Instituta za etnologiju i folkloristiku u kojoj je trebala biti objavljena (u suizdavaštvu s Institutom društvenih znanosti "Ivo Pilar"). Upravo to se dogodilo zborniku Didov san: transgranična iskustva hrvatskih iseljenika.

U obrazloženju o neprihvatljivosti ${ }^{7}$ njegova objavljivanja u toj biblioteci miješaju se prigovori i kritike u rasponu od znanstvene diskreditacije do političke difamacije urednica i pojedinih autora. Između ostaloga, dopis navodi da oprema cjeline zbornika jednostavno nije dorasla istraživanju iseljeništva, niti u načinu refleksije pojedinačnih povijesnopolitičkih činjenica niti u samom znanstvenom smislu, da predgovor sadrži znanstveno

7 Mišljenja iz toga dopisa kao i iz nekih drugih izjava kolega iz Instituta za etnologiju i folkloristiku neće biti navođena doslovno i uz indikaciju autora, jer riječ je o neobjavljenim, javnosti nedostupnim dokumentima, pismima i zapisnicima. Da bi se te izjave razlikovale od doslovno citiranih mišljenja iz javno dostupnih tekstova, bit će kurzivirane. 
prevladano esencijalističko poimanje nacije, da je korištenje eufemizma o kazivačima kao "malim" $i$ "običnim ljudima” prevladano u suvremenoj etnografiji i slično. Zborniku se predbacuje i ravnodušno (ili tendenciozno) neinformiranje čitatelja o kontroverznim pozadinama pojedinih događaja $i$ autora i spominjanje $u$ apsolutno pozitivnom kontekstu uloga osoba poput Maksa Luburića ili Srećka Pšeničnika. Da su urednice imale skrivenu političku namjeru imputirano je i u pokušaju nekih kolega da dobiju podršku tezi da zbornik zlorabi etnografsku metodu ustupanjem prava glasa pojedincima koji u pozitivnom svjetlu govore o ratnim zločincima iz Drugog svjetskog rata i njihovom "patriotskom radu” u hrvatskoj dijaspori. Krajnje apsurdna manipulacija u kontroverzama oko zbornika bila je i insinuacija da je naslov zbornika politički motiviran te da upućuje na Eugena Didu Kvaternika, visokopozicioniranoga ustaškog dužnosnika u Nezavisnoj Državi Hrvatskoj.

Osporavatelji zbornika ponajviše su se bavili jednim od autora, Marinom Soptom. ${ }^{8}$ Sopta je autor teksta o ulozi hrvatskih iseljenika $\mathrm{u}$ događajima vezanima uz hrvatski rat za neovisnost 1990-ih godina (Sopta 2014a). ${ }^{9} \mathrm{U}$ tom osobnom povijesnom svjedočenju autor opisuje iseljeničke aktivnosti u Kanadi 1990-ih iz svoje dvostruke uloge, kao svjedoka i sudionika. Premda ovdje nije riječ o znanstvenom pismu, čime se ovaj prilog znatno razlikuje od većine drugih priloga u zborniku, nakon što su o

8 Premda je taj autor, i sam iseljenik-povratnik, postao središnjom figurom svih rasprava i ocjena zbornika, urednice mu nisu namijenile tu ulogu. Njegovi su prilozi stavljeni u središte kontroverzi manipulacijama kritičara, a na račun drugih priloga, od kojih su neki stožerni prilozi i u teorijskom, epistemološkom i metodološkom smislu.

9 Taj je rad preuzet iz autorove monografije Hrvati u Kanadi: oblikovanje hrvatske zajednice od 1945. do 1995. (Sopta 2012:353-379) i objavljen s manjim lektorskim izmjenama. Nakon što je objavljena, ta monografija nije, barem koliko mi je poznato, izazvala kontroverzu sličnu onoj do koje je došlo nakon njezina djelomična ponovna objavljivanja u zborniku Didov san. To može navesti na pitanje o tome ne selektiraju li kritičari svoje napade i jesu li ti napadi zaista isprovocirani samim Soptinim tekstovima i njihovim sadržajem ili drugim, neakademskim pitanjima. Može se postaviti i pitanje je li suprotstavljeni ideološki narativ ustaše - partizani/komunisti bio slabiji 2012. godine jer Soptina monografija tada nije izazvala reakcije kao reprint jednoga njezina dijela dvije godine kasnije. 
tome raspravljale, urednice su ipak odlučile da ga objave jer su u zbornik željele uključiti poglavlje o kanadskim Hrvatima. Očekivale su da će uz pomoć biografskog intervjua s autorom (v. Sopta 2014b) dobiti kontekst nužan za razumijevanje autorova prikaza iseljeničkih aktivnosti u 1990ima. Međutim, Sopta je odbio dati biografski intervju te je razgovor koji sam s njim vodila usmjerio prema javnim percepcijama hrvatske dijaspore, političkim nastojanjima za povratkom i strateškim planiranjem povratka hrvatskih iseljenika, nerijetko koristeći, kako je to sarkastično primijetila Renata Jambrešić Kirin (2014:217), autoritet majestetskog plurala. Kao i svi drugi razgovori objavljeni u zborniku, i ovaj je skraćen, iskazi su tematski okupljeni u cjeline, te je tako uređeni tekst poslan na autorizaciju, tijekom koje je Sopta dopisao neke dijelove (v. Sopta 2014b).

Osporavatelji zbornika kritizirali su oba priloga. Složila bih se $\mathrm{s}$ njihovom ocjenom da je Soptinu tekstu o kanadskim Hrvatima (Sopta 2014a) teško utvrditi elementarni znanstveni (društveno-humanistički) značaj. ${ }^{10}$ No, ne bih olako dovela u pitanje Soptinu poziciju kao svjedoka i sudionika događaja o kojima piše. Naime, standardna antropološka formula tvrdi da svjedok nosi posebno znanje i moralni autoritet te da nije podložan uobičajenim pravilima dokazivanja (Marcus 1998; v. i Banac 2014b).

Još kontroverznijim se autorima obrazloženja o neprihvatljivosti zbornika učinilo Soptino spominjanje Vjekoslava Luburića u razgovoru koji sam s njime vodila (Sopta 2014b:103). ${ }^{11}$ Osporavatelji zbornika smatrali su, kako je već navedeno, da je Luburić spomenut u apsolutno pozitivnom kontekstu. Pri toj ocjeni previdjeli su da je Sopta nijansirao svoj iskaz te uputio na apsurd da zloglasni ustaški dužnosnik promovira ideju pomirenja ustaša i partizana. To se može čitati kao svojevrsna distanca

\footnotetext{
10 Drugi su autori upozorili kako je Soptin tekst "tendenciozan" (Banac 2014b:3) i “ideološki obojen” (Rogelja 2015:162).

11 Kao i urednička odluka da hrvatskim čitateljima nije potrebno posebno objašnjavati tko je Luburić. Kako ne bih ponovno izazvala kritike, navodim kratke enciklopedijske informacije: Luburić, Vjekoslav (Maks), hrvatski političar (1914.-1969.). Jedan od najistaknutijih organizatora ustaškog terora, napose zloglasnih logora s desecima tisuća civilnih žrtava. Od 1948. djelovao u Španjolskoj; osnivač Hrvatskog narodnog otpora i izdavač emigrantskih listova. Ubijen u atentatu jugoslavenskih tajnih službi (http:// proleksis.lzmk.hr/3177/).
} 
i komentar na Luburićevu navodnu ulogu u ideji pomirenja. ${ }^{12}$ Sporni odsječak zaslužuje da ga se u potpunosti navede, kako bi se izbjegle daljnje manipulacije njegovim sadržajem:

"No s vremenom, kako dolazi do otopljenja odnosa zapadnoga i istočnoga bloka, pa '68. je također učinila svoje, javlja se ideja nacionalnog pomirenja i suradnja s hrvatskim komunistima. Prvi idejni začetnik toga bio je general Luburić, što zvuči apsurdno. On je taj koji govori o ideji nacionalnog pomirenja, daje proglas hrvatskim komunistima o potrebi zajedničkog djelovanja u borbi za hrvatsku samostalnost. Imajući u vidu njegovu reputaciju, nitko ga nije mogao optužiti da je udbaš. ${ }^{13 "}$ (Sopta 2014b:103)

Da bi se ovaj pasus interpretirao, kao što to čini Jambrešić Kirin (2014:215), kao “znanstvenom tekstu' ${ }^{14}$ neprispodobivu zloporabu povijesti i uzdizanje ratnog zločinca iz NDH-a u 'mirotvornu figuru' hrvatskog emigracijskog pokreta" i kao "pokušaj rehabilitacije Vjekoslava 'Maksa' Luburića", te da se temeljem toga zaključuje kako se cijeli zbornik "priklonio dominantnom populističkom diskursu o prošlosti koji nema za cilj znanstveno relevantno suočavanje s prošlošću već 'čišćenje' pojedinih ideologija od bremena povijesti i podržavanje njima bliskih suvremenih političkih opcija" impresivna je intelektualna bravura i vrhunska manipulacija. ${ }^{15}$ Ona zahtijeva zavidan stupanj maštovitosti i

${ }^{12}$ Spominjući Luburića, Sopta se vjerojatno referira na kontroverznu Tuđmanovu biografiju iz pera novinara Darka Hudelista u kojoj autor Luburiću pripisuje ideju pomirenja dviju sukobljenih ideologija i pozicija. Prvi hrvatski predsjednik Franjo Tuđman tu je ideju navodno preuzeo od Luburića (v. Pavlaković 2014:35).

${ }^{13} U d b a s ̌$ je suradnik Udbe, Uprave državne bezbednosti, jugoslavenske tajne policije.

${ }^{14}$ Lakoća kojom Jambrešić Kirin iznosi tendenciozne tvrdnje na račun zbornika razvidna je i u načinu na koji se odnosi prema faktografiji. Tako se razgovor sa Soptom ne može okarakterizirati kao "znanstveni tekst", a Katarina Brozović-Bašić nije "višekratna povratnica iz Kanade”, kako kaže Jambrešić Kirin (2014:217).

15 Unatoč tomu, neki je znanstvenici preuzimaju pa tako Hameršak, Pavlić i Perica (2015:169) navode "najeklatantniji primjer" relativizacije prošle stvarnosti iz zbornika Didov san - "rehabilitaciju zapovjednika koncentracijskog logora Jasenovac". Bilo bi zanimljivo doznati u kojim se to drugim primjerima također relativizira prošlost. Ovakvo 
zlonamjernosti, osim ako nije vođena ideološkim stavom analognim onome kojeg nastoji kritizirati, no sama mu ne uspijeva izmaknuti. U tome smislu, ta manipulacija nije nimalo različita od senzacionalističke novinarske izjave da Soptin članak "izravno negira zločine ustaškog režima i njegovu narav" (Ponoš 2014), ${ }^{16}$ da cijeli zbornik "reafirmira ustaštvo, barata nacionalnim predrasudama bez ikakvog znanstvenog utemeljenja [...]", te da je Ministarstvo znanosti, obrazovanja i sporta sufinanciralo zbornik "proustaških radova" (ibid.).

Jednom drugom autoru u zborniku, Velimiru Piškorcu (2014), predbačeno je u obrazloženju neprihvatljivosti zbornika da inzistira na pejorativu komunistički kao oznaci za represivni i totalitarni jugoslavenski režim. Kao komentar ovoj primjedbi, mogu se samo zajedno s Bancem upitati, "što bi tu bilo sporno i zašto bi pridjev 'komunistički', koji za politički poredak pod vlašću lenjinsko-komunističkih partija rabi cijeli svijet, bio pejorativan?" (Banac 2014b:3). ${ }^{17}$ Piškorec je također kritiziran zbog toga što ovlaš uvodi temu Bleiburga ${ }^{18}$ u svoj rad, jer ona je prema autorima obrazloženja do dan danas, $i$ u svojoj povijesnoj složenosti $i$ u

nekritično prenošenje fabrikacije o povijesnom revizionizmu zbornika (prisutno i u Pleše 2014:25), štoviše od kolegica iz Instituta za etnologiju i folkloristiku, neshvatljivo je i posve na rubu pameti. Radnja i neki likovi toga Krležina romana izvrsno opisuju ovu institutsku dramu.

16 Tihomir Ponoš, 2014, "Revizija povijesti - Ministarstvo znanosti sufinanciralo zbornik - proustaških radova". http://www.novilist.hr/Vijesti/Hrvatska/Revizija-povijestiMinistarstvo-znanosti-sufinanciralo-zbornik-proustaskih-radova (pristup 11. 2. 2015.).

17 Zanimljivo je u tom kontekstu pročitati komparativnu analizu Macieja Czerwińskog (2013) o razlici u kulturnim kodovima odnosa prema komunizmu u Poljskoj i Hrvatskoj.

18 Bleiburg (slovenski Pliberk), austrijski gradić na granici sa Slovenijom u kojem je angloameričko zapovjedništvo predalo jedinicama JNA (Jugoslavenske narodne armije) zarobljene ustaše, domobranske postrojbe i civile koji su se njima predali nakon povlačenja iz Zagreba i Hrvatske; nakon predaje jedinice NOVJ (Narodnooslobodilačke vojske Jugoslavije), pod zapovjedništvom generala Koste Nađa, izvršile su masovna smaknuća zarobljenika. O broju poginulih na Bleiburškom polju i na kasnijem križnom putu daju se različite procjene; prema demografu Vladimiru Žerjaviću riječ je o oko 50000 osoba (http:// proleksis.lzmk.hr/12602/; pristup 11. 2. 2015.). Usput napominjem da je enciklopedijski članak nedosljedan u imenovanju vojske koja je izvršila smaknuća zarobljenika. 
utvrđivanju službene terminologije predmet slojevitih rasprava hrvatske i svjetske historiografije. Upozorivši na detaljnu i objektivnu obradu teme Bleiburga u svjetskoj historiografiji, Banac je ovo mišljenje proglasio izrazom "restauracijskog vala" i ideologizirane hrvatske znanosti, u naciji koja "boluje od patološke samodestrukcije, samoubilačke ideologizacije" (Banac 2014b:3). Navedene kritike na Piškorčev prilog ilustriraju način na koji funkcionira "crveni totalitarizam" u Hrvatskoj: on pokušava relativizirati i negirati zločine komunista (ovdje Bleiburg) (usp. Czerwiński 2013:56). Takav je postupak Maciej Czerwiński (ibid.) nazvao “čišćenjem” jedne ideologije osporavanjem njezinih zločina.

Znanstvenici u Institutu za etnologiju i folkloristiku autori su mnogih drugih, pisanih i usmenih, "službenih" i "neslužbenih" izjava o zborniku Didov san. Većina je do danas pohranjena u privatnoj elektroničkoj razmjeni i dokumentima koji javno nisu dostupni. U njima su stigme "ustaša" i "proustaški" stalno iznova rabljene, bez osobite zadrške ili osjećaja odgovornosti za težinu difamacije. Jedan je autor priloga proglašen ustašom; suprug jedne suurednice označen je znanstvenikom koji rehabilitira ustaški pokret; cijeli je zbornik dobio epitet proustaški, itd. Na osnovi eseja Umberta Eca, Ur-Fascism, ${ }^{19}$ jedna je kolegica u zborniku identificirala sedam mjesta na kojima se ustaštvo navodno spominje u pozitivnom ili u negativnom svjetlu (sic!). Doista, skriveni od javnosti, znanstvenici, osporavatelji zbornika, obilno su se i arbitrarno koristili diskreditirajućom etiketom "ustaša" za zbornik, pojedine cjeline, urednice i autore.

No, tek novinar Novog lista, već spomenuti Tihomir Ponoš, nije izbjegao javno upotrijebiti inkriminirajuću etiketu u naslovu svoga članka u kojem izvještava o zborniku: "Revizija povijesti - Ministarstvo znanosti sufinanciralo zbornik - proustaških radova" te je zbornik i preimenovao u Didov ustaškonostalgični san (Ponoš 2014). ${ }^{20}$ Tako se akademska debata koja je do tada u javnosti ostavila samo ponešto nejasan trag prilikom

19 U hrvatskom prijevodu, Esej o vječnom fašizmu (http://www.lupiga.com/vijesti/ umberto-eco-esej-o-vjecnom-fasizmu; pristup 15. 2. 2015.)

${ }^{20}$ Vidjeti bilj. 13. Odgovor MZOS-a v. na: (http://www.tportal.hr/vijesti/hrvatska/323447/ MZOS-Didov-san-nije-zbornik-proustaskih-radova.html; posjet 15. 2. 2015.). 
predstavljanja zbornika u Matici hrvatskoj te u HRT-ovoj emisiji Pola ure kulture, ${ }^{21}$ prelila u najširu moguću javnu domenu. Ponošev je članak bio tako napisan da je poznati hrvatski intelektualac i društveni kritičar, u privatnom pismu upućenom mi, kazao da se čitajući Ponošev tekst osjećao kao iz vremenskog stroja, u dobu u kojemu je Centralni komitet Komunističke partije na sličan način pozivao na linč. Kazao je i kako je Ponošev tekst točna zrcalna slika napada s kojim je javno dočekana knjiga Snježane Kordić, Nacionalizam i jezik. ${ }^{22}$

Slično tomu, novinar Mate Bašić (2014) napisao je kako je Ponošev prilog "otvorena ideologizirana kampanja rigidne ljevičarske provenijencije, s brutalnim medijsko-političkim udarom, ovoga puta, na hrvatsku akademsku zajednicu" sročena "u maniri [...] ocjena negdašnjih ideoloških komisija centralnih komiteta". ${ }^{23}$ Bašić je zaključio kako je cijela kontroverza "akademski obračun", "napad" na "cijeli think-tank tzv. desničarskoemigrantski (u nedostatku bolje etikete) s kojim se nesvjesna, ali drska tzv. antifašistička ljevica (opet u nedostatku bolje etikete) želi obračunati, i zapriječiti im, ovoga puta, i akademski, znanstveni prostor" (ibid.).

\section{REAKCIJE AUTORA ZBORNIKA： IDEOLOŠKI SUPROTSTAVLJENE POZICIJE}

Osobe uključene u zbornik, bilo da je riječ o urednicama ili o autorima priloga, na različite su načine reagirale na optužbe iznesene na njihov račun ili na račun cjeline zbornika. Njihove su reakcije pokazale, da upotrijebim riječi Jadranke Čačić-Kumpes, da se "pretpostavljena

${ }^{21}$ HRT, 19. 3. 2014 (http://www.hrt.hr/enz/pola-ure-kulture/238709; pristup 3. 3. 2015.). Tjedan dana kasnije uslijedio je i demanti tadašnjeg ravnatelja Instituta za etnologiju i folkloristiku Tvrtka Zebeca na izjavu danu u prethodnoj emisiji (Pola ure kulture, 26. 3. 2014.).

${ }^{22}$ Knjiga je izazvala brojne komentare zbog teze da su hrvatski i srpski jedan jezik. Vidi: http://snjezana-kordic.from.hr/o-knjizi-jezik-i-nacionalizam/; pristup 15. 2. 2015.

23 Mate Bašić, 2014, Noćna proustaška mora u Didovu snu. http://objektivno.hr/matebasic-nocna-proustaska-mora-u-didovu-snu-28420 (pristup 15. 2. 2015.). 
vrijednosna neutralnost" kojoj je zbornik težio, "uslijed pristranosti aktera, povija poput vrbe na vjetru te da nerijetko doseže granicu na kojoj prestaje vrijediti načelo sine ira et studio, čak i tada kada je riječ o diskursu koji pretendira biti znanstvenim" (Čačić-Kumpes 2014:249).

Kad sam nekim autorima predložila da izostavimo njihov prilog ili da izmijenimo neke njegove dijelove, optužili su me da ih cenzuriram. Ta je optužba bila dijametralno suprotna onoj koja me sustizala sa strane osporavatelja zbornika: za jedne bila sam komunistički cenzor, za druge sam podržavala ustaštvo ili sam barem otvorila diskurzivni prostor za ekstremno-desne ideje i mišljenja.

Dok su neki autori odbili učiniti bilo kakve promjene u svojim prilozima, jer bi to za njih značilo da se slažu sa sumnjivom kritikom koju su tumačili kao komunističku cenzuru, neki su odlučili izmijeniti dijelove svoga priloga ne bi li izbjegli daljnja tendenciozna čitanja. Kako se ne bi našli u stigmatiziranom zborniku dio je autora odlučio povući svoj prilog. ${ }^{24}$ Jedan je autor objasnio tu odluku u pismu koje je mješavina osobnih, ideoloških $\mathrm{i}$ ispolitiziranih no ne i znanstvenih razloga. Osobna i obiteljska povijest, pokušaji da se distancira od ustaške stigme kojoj je obitelj navodno bila izložena, premda su bili partizani, kao i Google pretraga pojedinih urednica zbornika navele su tu osobu da povuče svoj tekst.

Internetske izvore o M. Sopti koristila je još jedna osoba koja je odlučila povući tekst. Ona je ocijenila kako Sopta u raznim istupima negira povijesne činjenice, naginje ustaštvu, eugenici i kulturnom rasizmu. Kao i prethodna osoba, i ova je izrazila strah da bi objavljivanje u zborniku u kojem je jedan od autora Sopta, naštetilo njezinu imenu i reputaciji.

Objašnjenja pak treće osobe koja je povukla prilog bila su nedosljedna. $\mathrm{S}$ jedne strane, Soptinu političku poziciju nije smatrala problematičnom već poželjnom; s druge, ta je osoba mislila da su joj urednice dale previše prostora nauštrb drugih pozicija. Prezentacija intervjua sa Soptom također

24 Oklijevala sam iznijeti mišljenja suradnika koji su povukli tekstove. Ipak, odlučila sam se to učiniti, u vrlo sažetom obliku, jer njihova objašnjenja, s jedne strane, izvrsno ilustriraju tezu da su u pozadini nastalog prijepora politizacija i ideologija, a s druge, pokazuju razmjere straha i paranoje koje pripisivanje ustaštva u hrvatskom društvu može donijeti involviranim akterima. 
se navodi kao problematična (no ne i prezentacija drugih razgovora). Objašnjenja poput intervju gospodina Sopte ne ostavlja dojam kazivačkog intermezza koliko plana koji svoju legitimaciju pronalazi u jednom znanstvenom zborniku ili naša je perspektiva kompromitirana Soptinim tekstom, podupiru dojam kako je i ovdje riječ o insinuaciji o skrivenoj političkoj agendi Sopte i zbornika te o ispolitiziranoj odluci autora da povuče svoj tekst.

Za sva je tri autora sablast ustaštva i fašizma očito još uvijek živa i željeli su se posve distancirati od zbornika koji je proglašen proustaškim. Doista, reputacija koju je zbornik dobio postala je moćna i zastrašujuća etiketa koje se valjalo kloniti.

\section{PONAD IDEOLOGIJE}

Ipak, zbornik je u više navrata ocijenjen i izvan ispolitizirane ideološke matrice. Jedna od prvih medijskih prezentacija bila je kratka gotovo poetska zabilješka iz pera književnika i novinara Ivice Prtenjače (2014). ${ }^{25}$ Slično se o zborniku izrazio i povjesničar Jozo Džambo (2015), zapisavši:

"Razgovor s Katarinom Brozović-Bašić, kćerkom hrvatskog emigranta, rođenoj u Australiji, savršena je ilustracija u zborniku zastupljenih (hipo)teza, a istovremeno i dramatična ispovijest osobe koja, unatoč svemu, ipak nalazi vlastite autentične odgovore i uspijeva sačuvati životnu ravnotežu. Možda bi lektiru knjige trebalo početi upravo s ovim tekstom. Osim toga ova priča nije ni bez literarnih kvaliteta - to je usmenost koja je preživjela sva putovanja i udaljenosti, sve lomove jezikā i kulturā - snažan, fascinirajući govor." (Džambo 2015:21)

Nadalje, djelatnica Matice iseljenika, Vesna Kukavica, detaljno je predstavila sadržaj zbornika (Kukavica 2014). Do sada je nastalo i nekoliko znanstvenih prikaza zbornika, od kojih je jedan usmena prezentacija na

25 Ivica Prtenjača, 2014, Transgranična iskustva hrvatskih iseljenika (http://www.vecernji. hr/knjige/transgranicna-iskustva-hrvatskih-iseljenika-927123; pristup 3. 3. 2015). 
predstavljanju knjige sociologa Ivana Rogića, ujedno i recenzenta zbornika, a drugi su objavljeni u raznim domaćim i stranim časopisima (Čačić-Kumpes 2014; Udier 2014; Perić-Kaselj 2014; Rogelja 2015). Premda se razlikuju u opsegu, sadržaju i kritici pojedinih radova i cjeline zbornika, nijedan u zborniku ne nalazi rehabilitaciju ustaštva niti manipulira njegovim sadržajem.

Nataša Rogelja ustanovljava da "ideološki obojen" "esej” M. Sopte "na prvi pogled" predstavlja "neobičan izbor urednica zbornika", no da je njime ilustrirana ideja "autonomnosti glasova" različitih autora te time realizirana namjera urednica da se predstave "heterogenaiskustvai stajališta" (Rogelja 2015:162, prijevod sa slovenskog J. Č.). Slično su konstatirale i Jadranka Čačić-Kumpes (2014) i Sanda Lucija Udier (2014). U opsežnom kritičkom osvrtu na zbornik, Čačić-Kumpes uočava različite analitičke razine i stilove pisanja autorskih tekstova, smatrajući da su urednice s više "uređivačke rigoroznosti" spram Soptina i Piškorčeva priloga, za koje drži da predstavljaju, odnosno prenose "subjektivno svjedočanstvo iseljeničkog iskustva" mogle izbjeći prijepore (Čačić-Kumpes 2014:249).

Bez obzira na te kritike upućene zborniku, važna je činjenica da ovi znanstveni osvrti nisu pronašli traga historijskom revizionizmu. To potvrđuje tezu kako su politički inkriminirajuće ocjene zbornika od strane znanstvenika iz Instituta za etnologiju i folkloristiku i jednog novinara u prvom redu bile fabrikacije.

\section{PODJELA NA "CRVENE" I "CRNE"}

Izloženi materijal govori u prilog tezi da insinuacije na račun zbornika imaju izvorište u ideološkom sukobu kojim je hrvatsko društvo podijeljeno na dva nepomirljiva tabora, koje se ponekad naziva "crnima" i "crvenima". Podjela teče simboličnom razdjelnicom između sukobljenih memorija o ustašama i antifašističkim borcima, partizanima. U javnim predodžbama, antifašisti se ne razlikuju od komunističkih revolucionara koji su došli na vlast u novoj Jugoslaviji nakon Drugoga svjetskog rata. Nijednom od tih memorija nije se na odgovarajući i kritičan način bavilo u postkomunističkoj Hrvatskoj. Obje su još uvijek žive i dijele suvremeno društvo, dok ih političari koriste za vlastite svrhe. Razlikovne politike povijesti i diskursi o prošlosti dviju glavnih političkih stranaka kao i 
njihova manipulacija u dnevnopolitičke svrhe sprečavaju da "prošlost postane povijest" (Pavlaković 2009:193). Isti je fenomen nedavno uočen u kontekstu bujanja memorija u drugim europskim zemljama (Langenbacher, Niven i Wittlinger 2012:3). U Hrvatskoj, one se uvlače u svakodnevnu politiku, društvo, kulturu i znanost, čime svaki društveni čin postaje ujedno i politizirani događaj. To drži društvo u stanju napetosti, ali i blokade, jer se stalno iznova provocira (politička) kriza. U sinergiji s dubokom ekonomskom krizom, što se istodobno potiskuje u pozadinu emocionalno nabijenim neriješenim memorijama i ideološkim sukobima, nastaje plodno tlo za političke manipulacije.

Podjela na "crvenu” i “crnu” Hrvatsku potječe iz 1930-ih. U to doba nastaju radikalni politički pokreti, ustaški i komunistički, koji poslije stvaraju državu, jedan kratkotrajnu Nezavisnu Državu Hrvatsku (NDH), drugi komunističku Jugoslaviju što nastaje na antifašističkoj borbi protiv, među ostalima, ustaške NDH. Ta dva suprotstavljena pokreta potaknula su duboke ideološke podjele i rezultirala naslijeđima nasilja na obje strane (Pavlaković 2014).

Nakon Drugoga svjetskog rata, komunističkaje diktatura odredila čega se i kako hrvatska populacija treba sjećati (Cipek 2009:157). Postojala je jedna službeno priznata memorija, ona antifašističkih boraca. Komunistički se sustav legitimirao na glorifikaciji i poistovjećivanju s antifašističkom, partizanskom borbom (Czerwiński 2013). Sudionici Narodnooslobodilačke borbe (NOB) bili su, prema Cipekovu tumačenju (2009), sakralizirani, a njihova je karizma sakralizirala komunističku ideologiju i cjelokupan komunistički sustav, izdigavši ga ponad svake kritike. Dok je kanonska komunistička memorija obilježavala mitologiziranu partizansku borbu, prešućivala je ratne i poratne komunističke zločine protiv ustaša i drugih ideoloških neprijatelja, isključujući ih iz službenih memorijalizacija i komemoracija. Hrvatima je nametnuta kolektivna krivnja zbog postojanja ustaške države, a ustaški koncentracijski logor Jasenovac postao je simbol komunističke antifašističke borbe (Pavlaković 2008, 2009). No, neslužbene memorije ostale su žive tijekom komunističke vlasti; održavane su u obiteljima poraženih ustaških snaga koje su otišle u emigraciju, njegovane su među drugim (e)migrantima i domaćom populacijom antikomunističke i antijugoslavenske orijentacije (ibid.; Cipek 2009). 
Nestanak komunizma i demokratizacija 1990-ih donijele su "osvetu zabranjene memorije". Do tada zabranjivane memorije koje su uključivale i ustašku memoriju, ali na nju ne mogu biti svedene, postale su javne. Neposredna posljedica toga bila je propitivanje uloge pobjedničkih antifašističkih boraca, do tada zaštićenih od svake kritičke procjene zločina koje su počinili protiv ustaša ali i svih drugih ideoloških neprijatelja. U svojem ekstremnom obliku, to je propitivanje dovelo do kriminalizacije i demonizacije pobjednika u Drugom svjetskom ratu i do rehabilitacije poraženih ustaša (Cipek 2009; Pavlaković 2008, 2009, 2012). Upravo su ta dva procesa predstavljala dvije strane onoga što je nazvano povijesnim revizionizmom (v. bilj. 1). Uz to, u tim procesima rememorijalizacije, analizira Vjeran Pavlaković, partizani-komunisti su etnicizirani kao Srbi, a u kontekstu srpsko-jugoslavenske agresije na Hrvatsku 1991. godine, događaji iz 1945. reinterpretirani su kao identični onima iz 1991. Reinterpretacija partizansko-komunističke osvete i zločina protiv njihovih ideoloških neprijatelja kao srpskih zločina protiv Hrvata dobro se uklopila u ratne događaje 1990-ih i potvrdila je točnost te interpretacije. To je otvorilo prostor za manipulacije na obje strane u ranim 1990-im: srpski su vođe među Srbima u Hrvatskoj širili strah prijetnjom o "novom Jasenovcu"; Hrvati su prizivali mogućnost "novog Bleiburga", mjesta koje je u nacionalnoj svijesti simbol komunističko-partizanske osvete nad ustašama i civilima (uglavnom Hrvatima, Slovencima i Bosancima) u bijegu pred pobjedničkim komunistima (Pavlaković 2009:85ff).

U rukama političara i manipulatora, složena povijesna naslijeđa i heterogene memorije Drugoga svjetskog rata, komunizma i rata za neovisnost 1990-ih često su svedene na jednostavnu i lako uporabivu opoziciju koja izjednačuje antikomuniste s ustašama, a partizane s komunistima. Taj je totalizirajući stereotip kreiran u jugoslavensko doba. No, dok je tada bilo jasno koja je strana negativna, a koja pozitivna, u postjugoslavenskoj eri to nije posve jasno i procjena ovisi o poziciji iz koje osoba govori. Obje su jednadžbe generalizirajuće i povijesno netočne redukcije, jer niti su svi antikomunisti bili ustaše, niti su svi partizani bili komunisti (niti Srbi). Budući da se takva simplifikacija povijesne kompleksnosti može koristiti u ideološke i političke svrhe, njome se rado koristilo i u komunističko i u postkomunističko doba. Upravo se zato do danas rabi dajući plodno tlo za štetne političke manipulacije i diskreditiranje (političkih) protivnika. 
Svakodnevni je diskurs zasićen tim pojednostavljenim opozicijama u toj mjeri da su postale prazni označitelji.

Moć diskreditacije koju imaju začuđujuća je u svjetlu rezultata nedavnog istraživanja koje pokazuje da je Hrvatska bila vrlo uspješna u izgradnji nacije i osiguravanju lojalnosti populacije (istraživanje proveo Pavlaković 2014). I taj rezultat o uspješnoj integriranoj naciji govori u prilog tezi da je "crno-crvena" podjela u hrvatskom društvu umjetno reproducirana od strane političara i politiziranih medija. Njihov je diskurs tako efikasan da etiketiranje nekoga ustašom još uvijek biva vrlo snažno oružje za diskreditaciju, kao i proizvodnju snažnih emocija, kako to pokazuju reakcije aktera u kontroverzi oko zbornika Didov san: transgranična iskustva hrvatskih iseljenika.

Neki hrvatski društveni znanstvenici i intelektualci založili su se za postizanje konsenzusa glede hrvatske povijesti i memorije, kako bi se nadišlo sadašnje konfliktno stanje društva (Cipek; Pavlaković; Banac; Katunarić, između ostalih). Pozvali su na depolitizaciju svakodnevnog života i kulture, deideologizirana povijesna istraživanja, lustraciju, priznavanje pluralnosti žrtava, potrebu da se žrtvama odaje počast izvan dnevnopolitičkih manipulacija, i sl. Razmatranje hrvatskih sukoba oko memorije unutar širih europskih procesa rememorijalizacije također bi moglo biti korisno u pokušajima da se nadiđu trenutačne podjele i sukobi.

Ukratko, Bill Niven (2012) je ustvrdio da se Zapadna Europa morala konfrontirati samo s jednim totalitarnim režimom 20. stoljeća, nacizmom/fašizmom. To se dogodilo u dvije faze: narativ otpora i žrtve dominirao je razdobljem između 1950-ih i 1980-ih i bio je zamijenjen kritičkom konfrontacijom s holokaustom, u Njemačkoj od 1980-ih, u Francuskoj nešto kasnije. S druge strane, u posljednja dva desetljeća, Istočna Europa i Njemačka nakon ujedinjenja bile su istodobno izložene suočavanju s dvostruko opterećujućom prošlošću nacizma i komunizma. Otvaranje potisnutih narativa o viktimizaciji od strane komunizma nakon 1989. imalo je i drugu stranu: zahtjev za kritičkim suočavanjem s nacizmom/fašizmom. Suočavanje s posljednjim bilo je osobito teško u onim zemljama koje su uspostavile vlastite fašističke režime (Slovačka, Rumunjska, Hrvatska) (Niven 2012). Viktimizacijski diskurs u Njemačkoj 
rezultirao je izjednačavanjem nacizma i komunizma čime je istodobno došlo do slabljenja memorije holokausta (Wittlinger 2012). Prema Nivenu, istočnoeuropske zemlje su, s nekim razlikama, slijedile taj trend. Uza sve navedeno, komunizam je etniciziran kao ruski, sa svrhom pružanja samoopravdanja za sudjelovanje u komunizmu (Niven 2012).

Mnogi od navedenih procesa nalaze paralele $u$ hrvatskim procesima rememorijalizacije, uz dodatnu komplikaciju što je donosi Domovinski rat i sukobi oko njegove memorijalizacije kao i interakcija s druge dvije ključne memorije. Stoga bi usporedba hrvatskih iskustava s onima u drugim europskim zemljama ne samo pružila kontekst potreban za razumijevanje i ocjenu domaćih trendova- kao i kontekst u kojem bi bilo moguće deideologizirati hrvatsko društvo i znanost - nego bi bila informativna i za druge europske zemlje zbog bremena trostrukoga povijesnog naslijeđa i njihovih memorija u Hrvatskoj.

\section{LITERATURA}

BANAC, Ivo 2014a. "Živimo u verbalnom građanskom ratu” (razgovarao Andrija Tunjić). Vijenac, 23. siječnja, br. 519:4-5.

BANAC, Ivo 2014b. "Denuncijacija dijaspore". Vijenac, 17. travnja, br. 525:3.

BROZOVIĆ-BAŠIĆ, Katarina. 2014. "Dvostruki povratak: od Australije do Hrvatske i natrag" (priredila Jasna Čapo). U Didov san: transgranična iskustva hrvatskih iseljenika, ur. Jasna Čapo, Caroline Hornstein Tomić, Katica Jurčević. Zagreb: Institut za etnologiju i folkloristiku - Institut društvenih znanosti "Ivo Pilar", $147-173$.

CIPEK, Tihomir. 2009. "Sjećanje na 1945: čuvanje i brisanje. O snazi obiteljskih narativa”. U Kultura sjećanja: 1945. Povijesni lomovi i svladavanje prošlosti, ur. Sulejman Bosto i Tihomir Cipek. Zagreb: Disput, 155-165.

CLIFFORD, James. 1986. "Introduction: Partial Truths". U Writing Culture: The Poetics and Politics of Ethnography, ur. James Clifford i George E. Marcus. Berkeley: University of California Press, 1-26.

CZERWIŃSKI, Maciej. 2013. "Breme (post)komunizma. Hrvatski i poljski kulturni kodovi”. U Komparativni postsocijalizam. Slavenska iskustva, ur. Maša Kolanović. Zagreb: FF press, $47-80$.

ČAČIĆ-KUMPES, Jadranka. 2014. "Didov san: transgranična iskustva hrvatskih iseljenika, Jasna Čapo, Caroline Hornstein Tomić, Katica Jurčević, ur., Institut za 
etnologiju i folkloristiku i Institut društvenih znanosti Ivo Pilar, Zagreb, 2014., 288 str.”. Etnološka tribina, vol. 37:248-252.

ČAPO, Jasna, Caroline HORNSTEIN TOMIĆ i Katica JURČEVIĆ, ur. 2014a. Didov san: transgranična iskustva hrvatskih iseljenika. Zagreb: Institut za etnologiju i folkloristiku - Institut društvenih znanosti "Ivo Pilar".

ČAPO, Jasna, Caroline HORNSTEIN TOMIĆ, Katica JURČEVIĆ. 2014b. "Predgovor". U Didov san: transgranična iskustva hrvatskih iseljenika, ur. Jasna Čapo, Caroline Hornstein Tomić, Katica Jurčević. Zagreb: Institut za etnologiju i folkloristiku Institut društvenih znanosti "Ivo Pilar", 9-13.

DŽAMBO, Jozo. 2015. “Transgranična iskustva hrvatskih iseljenika”. Živa zajednica, ožujak-travanj 2015, br. 3-4 (352):21.

GUDEHUS, Christian. 2012. "Remembering World War II in Europe: Structures of Remembrance". U Dynamics of Memory and Identity in Contemporary Europe, ur. Eric Langenbacher, Bill Niven i Ruth Wittlinger. New York - Oxford: Berghahn Books, 69-87.

HAMERŠAK, Marijana, Goran PAVLIĆ i Ivana PERICA. 2015. "Suvremene znanstvene i obrazovne politike: bez točke iz koje je moguće pomaknuti svijet”. U Jezične, kulturne i književne politike. Zbornik radova 43. seminara Zagrebačke slavističke škole. Zagreb: Filozofski fakultet, 155-178.

HOLMES, Douglas R. 1993. “Illicit Discourse”. U Perilous States: Conversations on culture, politics, and nation, ur. George E. Marcus. Chicago - London: The University of Chicago Press, 255-281.

JAMBREŠIĆ KIRIN, Renata 2014. “Je li etnologija znanost koja je iskočila iz tračnica?”. Etnološka tribina, vol. 37:212-219. DOI: 10.15378/1848-9540.2014.37.09

KATUNARIĆ, Dražen 2015. "Barbarogenij je junak našeg doba" (razgovarao Andrija Tunjić). Vijenac, 19. veljače, br. 547:4-5.

KORDIĆ, Snježana. 2010. Nacionalizam i jezik. Zagreb: Durieux.

KRLEŽA, Miroslav. 2000 [1938]. Na rubu pameti. Zagreb: HAZU - Matica hrvatska Naklada Ljevak.

KUKAVICA, Vesna. 2014. "Studije o novoj zavičajnosti hrvatskih migranata”. Matica, travanj 2014, 20-22.

LANGENBACHER, Eric, Bill NIVEN i Ruth WITTLINGER. 2012. "Dynamics of Memory and Identity in Contemporary Europe". U Dynamics of Memory and Identity in Contemporary Europe, ur. Eric Langenbacher, Bill Niven i Ruth Wittlinger. New York - Oxford: Berghahn Books, 1-13.

MARCUS, George E. 1998. Ethnography through Thick and Thin. Princeton: Princeton University Press. 
NIVEN, Bill. 2012. "German Victimhood Discourse in Comparative Perspective". U Dynamics of Memory and Identity in Contemporary Europe, ur. Eric Langenbacher, Bill Niven i Ruth Wittlinger. New York - Oxford: Berghahn Books, 180-194.

PAVLAKOVIĆ, Vjeran. 2008. "Flirting with Fascism: the Ustaša Legacy and Croatian Politics in the 1990s". U The Shared History: The Second World War and National Question in ex Yugoslavia. Novi Sad: Centar za istoriju, demokratiju i pomirenje, 115-144.

PAVLAKOVIĆ, Vjeran. 2009. "Komemorativna kultura Bleiburga, 1990-2009”. U Kultura sjećanja: 1945. Povijesni lomovi i svladavanje prošlosti, ur. Sulejman Bosto i Tihomir Cipek. Zagreb: Disput, 167-193.

PAVLAKOVIĆ, Vjeran. 2012. "Contested pasts, contested red-letter days. Antifascist commemorations and ethnic identities in post-communist Croatia". U Transforming National Holidays. Identity discourse in the West and South Slavic countries, 1985-2010, ur. Ljiljana Šarić, Karen Gammelgaard i Kjetil Ra Hauge. Amsterdam: John Benjamins Publishing Company, 149-169.

PAVLAKOVIĆ, Vjeran. 2014. "Fulfilling the Thousand-Year-Old Dream: Stretegies of Symbolic Nation-Building in Croatia". U Strategies of Symbolic Nation-Building in South Eastern Europe, ur. Pal Kolstø. Farnham: Ashgate, 19-49.

PERIĆ-KASELJ, Marina. 2014. “Jasna Čapo, Caroline Hornstein Tomić, Katica Jurčević, ur.: Didov san: transgranična iskustva hrvatskih iseljenika. Zagreb, Institut za etnologiju i folkloristiku, Institut društvenih znanosti Ivo Pilar, 2014., 288 str.”. Studia ethnologica Croatica, vol. 26:272-275.

PIŠKOREC, Velimir. 2014. "Migrantsko iskustvo u djelima đurđevečkog književnika Slavka Čambe”. U Didov san: transgranična iskustva hrvatskih iseljenika, ur. Jasna Čapo, Caroline Hornstein Tomić i Katica Jurčević. Zagreb: Institut za etnologiju i folkloristiku - Institut društvenih znanosti "Ivo Pilar", 43-75.

PLEŠE, Iva. 2014. Pismo, poruka, mejl: etnografija korespondencije. Zagreb: Institut za etnologiju i folkloristiku.

ROGELJA, Nataša. 2015. “Jasna Čapo, Caroline Hornstein Tomić, Katica Jurčević, (ur.), Didov san: Transgranična iskustva hrvatskih iseljenika, Institut za etnologiju i folkloristiku i Institut društvenih znanosti Ivo Pilar, Zagreb, 2014., 287 str.”. Dve domovine/Two Homelands, vol. 42:162.

ROGIĆ, Ivan i Ivan Čizmić. 2011. Modernizacija u Hrvatskoj i hrvatska odselidba. Zagreb: Institut društvenih znanosti "Ivo Pilar".

SOPTA, Marin. 2012. Hrvati u Kanadi: Oblikovanje hrvatske zajednice od 1945. do 1995. Zagreb: Institut društvenih znanosti "Ivo Pilar".

SOPTA, Marin. 2014a. "Prinos kanadskih Hrvata stvaranju i obrani Republike Hrvatske". U Didov san: transgranična iskustva hrvatskih iseljenika, ur. Jasna Čapo, Caroline 
Hornstein Tomić i Katica Jurčević. Zagreb: Institut za etnologiju i folkloristiku Institut društvenih znanosti "Ivo Pilar", 77-95.

SOPTA, Marin. 2014b. "Potreba strateškoga planiranja povratka: mišljenje povratnika Marina Sopte" (priredila Jasna Čapo). U Didov san: transgranična iskustva hrvatskih iseljenika, ur. Jasna Čapo, Caroline Hornstein Tomić i Katica Jurčević. Zagreb: Institut za etnologiju i folkloristiku - Institut društvenih znanosti "Ivo Pilar", 97-107.

UDIER, Sanda Lucija. 2014. "Hrvatska iznutra, Hrvatska izvana. Prikaz zbornika 'Hrvatska svakodnevica' urednica Jasne Čapo i Valentine Gulin Zrnić i zbornika 'Didov san' urednica Jasne Čapo, Caroline Hornstein i Katice Jurčević’. Kolo, časopis Matice hrvatske, vol. 3:260-268.

WITTLINGER, Ruth. 2012. "Shaking Off the Past? The New Germany in the New Europe". U Dynamics of Memory and Identity in Contemporary Europe, ur. Eric Langenbacher, Bill Niven i Ruth Wittlinger. New York - Oxford: Berghahn Books, 195-208.

Jasna Čapo Žmegač

\section{CONFLICTS OVER PAST HERITAGE AND MEMORY IN CROATIA:} AN ACADEMIC-LAY PUBLICATION IN THE GRIPS OF IDEOLOGY

The paper argues that vexed and divisive memories of Fascism and Communism persist in Croatia, with conflicts over memory regimes featuring in public discourse on an everyday basis, notwithstanding the fact that seventy and twenty-five years have elapsed since the collapse of the Ustasha (fascist) and communist regimes respectively. It is further argued that this memory divide is constantly reproduced by politicians and the mainstream media. Thus, what at first sight might appear to be empty signifiers - Communism and Fascismare constantly reinforced in everyday discourse. The argument is elaborated through examining a case study concerning allegations made against an academic-lay publication.

Keywords: ideology, politics, memory, Croatia 
